\title{
Very late thrombosis of a bare metal stent despite ongoing aspirin therapy after 10 years of implantation
}

\author{
Devameden aspirin tedavisine rağmen yerleştirilmesinden 10 yıl sonra çıplak \\ metal stentin oldukça geç trombozu
}

\section{Tolga Aksu*, Kazım Başer, Mine Koşar Durukan, Taner Şen, Ümit Güray}

Kardiyoloji Kliniği (Dr. T. Aksu), Kocaeli Derince Eğitim ve Araştırma Hastanesi TR-41900 Kocaeli, Kardiyoloji Kliniği (Dr. K. Başer, Dr. M. K. Durukan, Doç. Dr. Ü. Güray), Ankara Yüksek İhtisas Eğitim ve Araştırma Hastanesi TR-06230 Ankara, Kardiyoloji Kliniği (Dr. T. Şen), Kütahya Evliya Çelebi State Hospital, TR-43043 Kütahya

\begin{abstract}
Late stent thrombosis is a well-known complication of drug eluting stents. The recognized risk of late stent thrombosis associated with bare metal stents is too low. In this report, we present a 60 year old male patient who had an acute inferior myocardial infarction due to very late thrombosis (>10 years) of a bare metal stent. Intracoronary thrombus aspiration was performed and thrombus was extracted from the coronary artery with subsequent restoration of TIMI 3 distal flow. Very late stent thrombosis is an extremely rare complication of bare metal stents. With this case report we would like to emphasize the possibility of very late stent thrombosis with bare metal stent despite ongoing aspirin therapy.
\end{abstract}

Keywords: Bare metal stent, very late stent thrombosis

\section{Özet}

Çok geç stent trombozu ilaç kaplı stentlerin iyi bilinen bir komplikasyonudur. Çıplak metal stent ile ilişskili bilinen geç stent trombozu riski çok düşüktür. Bu vakada çıplak metal stentin çok geç trombozuna (>10 yıl) bağlı akut inferiyor miyokard infarktüsü tanısı konulan 60 yaşında bir erkek hastayı sunduk. İntrakoroner trombüs aspirasyonu yapıldı ve koroner arterden trombüsün temizlenmesi ile TIMI 3 akım elde edildi. Çok geç stent trombozu çıplak metal stentlerin çok nadir bir komplikasyonudur. Bu vaka ile biz devam eden aspirin tedavisine rağmen çıplak metal stent ile çok geç stent trombozu olasılığını vurgulamak istedik.

Anahtar sözcükler: Çıplak metal stent, çok geç stent trombozu

Geliş tarihi/Received: July 11, 2011; Kabul tarihi/Accepted: October 04, 2012

\section{*Corresponding author:}

Dr. Tolga Aksu, Kardiyoloji Kliniği, Kocaeli Derince Eğitim ve Araştırma Hastanesi, TR-41900 Kocaeli. E-posta: aksutolga@ gmail.com

\section{Introduction}

Coronary stents are widely utilized devices in contemporary interventional cardiology to obtain a reduction in coronary restenosis and abrupt vessel closure. However, attendant short and long term complications such as stent thrombosis and in-stent restenosis may have major clinical consequences. Late stent thrombosis is mostly associated with drug eluting stents (DES). In this report, a patient with acute inferior myocardial infarction due to very late stent thrombosis (>10 years) of the bare metal stent (BMS) is presented. 


\section{Case report}

A 60-year old male patient had undergone percutaneous coronary angioplasty to the right coronary artery (RCA) with a BMS 10 years ago for stable angina. He was on aspirin and ticlopidine dual therapy for the first month after implantation and continued merely with aspirin as sole antiplatelet therapy thereafter. Patient remained asymptomatic since his initial stent implantation and no invasive or noninvasive evaluation was performed. Ten years after BMS implantation, patient was admitted to emergency room with chest pain associated with ST segment elevation on the inferior leads of 12-lead electrocardiography. Patient denied any interruption of aspirin therapy. Coronary angiogram showed occlusion of RCA at the proximal segment of the previously implanted stent with high thrombus burden (Figure 1).

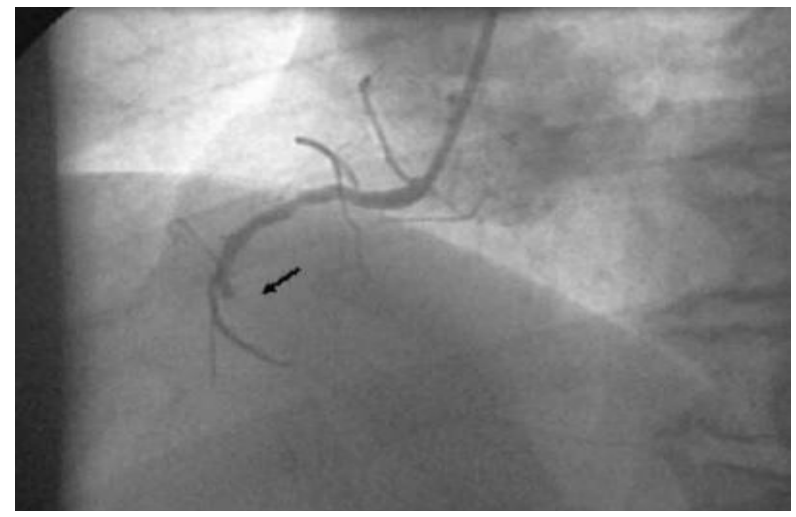

Figure 1. Coronary angiogram showing abrupt right coronary artery (RCA) occlusion at the proximal edge of a previously implanted bare metal stent.

Also, some in-stent restenosis was noted. Intracoronary thrombus aspiration was performed and thrombus was extracted from the coronary artery (Figure 2a), with subsequent restoration of the thrombosis in Myocardial Infarction (TIMI) 3 distal flow (Figure 2b).

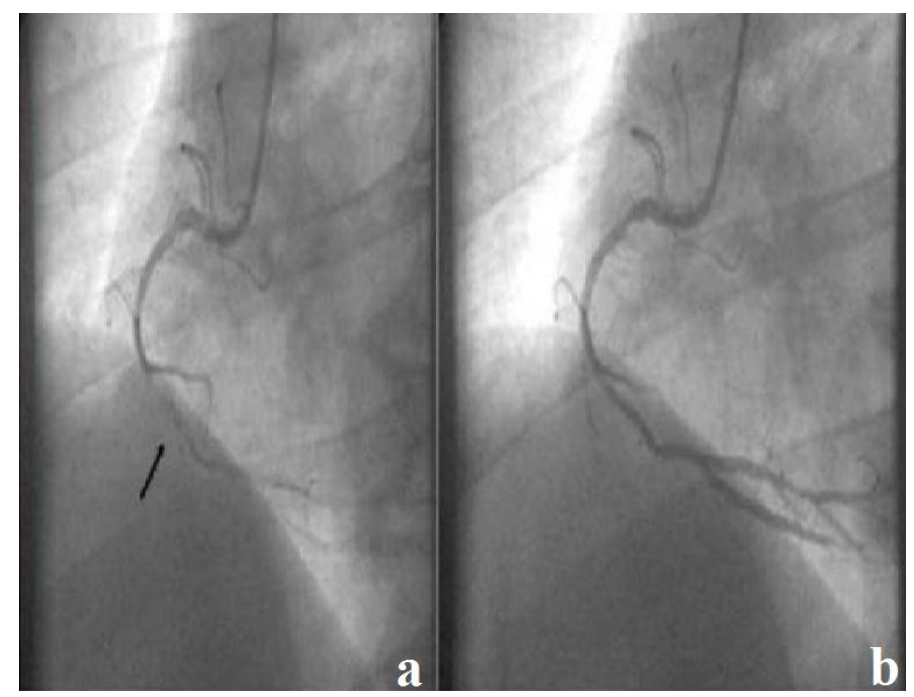

Figure 2a. Thrombus aspiration from mid RCA, b. Restoration of flow after thrombus extraction.

Glycoprotein IIb/IIIa inhibitor-tirofiban infusion was initiated with a bolus and 600mg of clopidogrel was administered orally. After appearance of the distal vessel, $3.0 \times 20 \mathrm{~mm}$ balloon was inflated within in-stent restenosis and good distal flow without significant stenosis was obtained (Figure 3). 


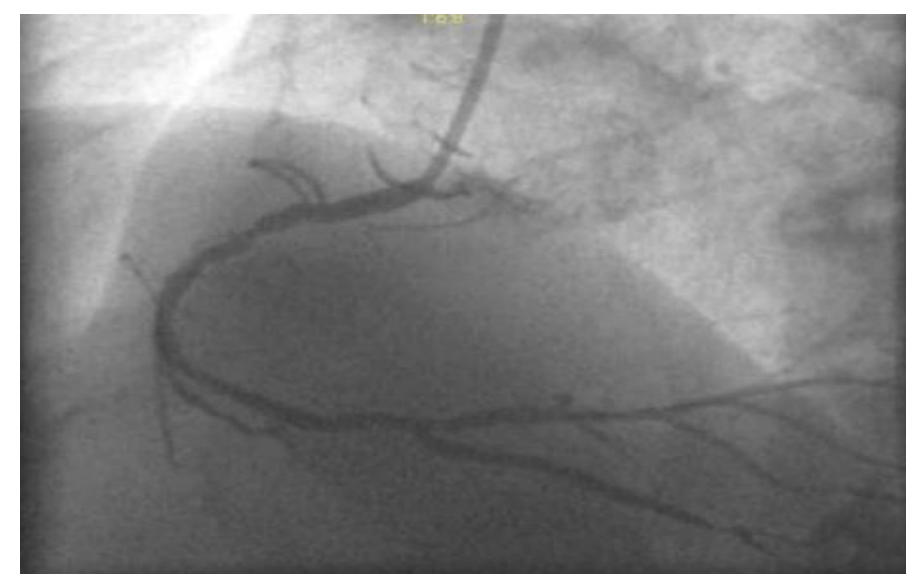

Figure 3. Successful reperfusion with TIMI 3 distal flow.

\section{Discussion}

Early and late stent thromboses have different underlying etiologic mechanisms. Late stent thrombosis is a well-known complication of DES. Namely fivefold higher risk of late stent thrombosis with the use of DES was reported as compared to the BMS [1].

Delayed neointimal healing causing incomplete endothelization, hypersensitivity, diffuse in-stent restenosis are major mechanisms of late thrombosis associated with DES, along with premature interruption of long term antiplatelet therapy [2] or antiplatelet therapy resistance [3].

The recognized risk of late stent thrombosis associated with BMS is too low [4]. In a report of Doyle et al, the incidence of stent thrombosis associated with BMS is $2 \%$ at 10 years and predictors of BMS thrombosis were; ulcerated lesions, vein graft intervention, prior myocardial infarction, prior coronary artery bypass graft operation, prior cerebrovascular accident, prior congestive heart failure and presence of peripheral vascular disease [5]. Generalized vascular inflammation may be the culprit pathophysiological mechanism. Degeneration of the healed intima with continuing atherosclerotic process in the long term may also result in BMS thrombosis.

Very late BMS thrombosis as we present is an extremely rare complication of BMS. In literature, reports of very late stent thrombosis occurring beyond 7 years are scarce $[6,7]$. To our knowledge, our report represents the longest event free duration of BMS in whom antiplatelet therapy was not discontinued. Our patient was hospitalized 10 years after his initial BMS implantation with a ST segment elevation myocardial infarction despite ongoing aspirin therapy. To date, there is only one report of a patient with BMS thrombosis 13 years after implantation, however this patient suffered a myocardial infarction after cessation of aspirin therapy [6].

We would like to underline the possibility of very late stent thrombosis that may be associated with BMS. When considering the need for long term antiplatelet therapy in the decision making of the type of the stent, dual antiplatelet therapy duration with BMS should be revised, although the efficacy of dual therapy remains unknown in long term.

\section{References}

1. Wang F, Stouffer GA, Waxman S, Uretsky BF. Late coronary stent thrombosis: Early vs. late stent thrombosis in the stent era. Catheter Cardiovasc Interv 2002; 55: 142-7.

2. Farb A, Burke AP, Kolodgie FD, Virmani R. Pathological mechanisms of fatal late coronary stent thrombosis in humans. Circulation 2003; 108: 1701-6.

3. Ong AT, McFadden EP, Regar E, de Jaegere PP, van Domburg RT, Serruys PW. 
Late angiographic stent thrombosis (LAST) events with drug-eluting stents. J Am Coll Cardiol 2005; 45: 2088-92.

4. Applegate RJ, Sacrinty MT, Kutcher MA, Santos RM, Gandhi SK, Baki TT, Little WC. "Off-label" stent therapy 2-year comparison of drug-eluting versus bare-metal stents. J Am Coll Cardiol 2008; 51: 607-14.

5. Doyle B, Rihal CS, O'Sullivan CJ, Lennon RJ, Wiste HJ, Bell M, Bresnahan J, Holmes DR Jr. Outcomes of stent thrombosis and restenosis during extended follow-up of patients treated with bare-metal coronary stents. Circulation 2007; 116: $2391-8$.

6. Sarkees ML, Bavry AA, Galla JM, Bhatt DL. Bare metal stent thrombosis 13 years after implantation. Cardiovasc Revasc Med 2009; 10: 58-9.

7. Fineschi M, Gori T. Very late thrombosis in a bare metal stent: An underrecognized problem. Can J Cardiol 2008; 24: e6-e7. 